\title{
IMPACT OF OXIDATION PROCESSES IN AN OXYGEN ION ENVIRONMENT ON THE PROPERTIES OF MOULDINGS FROM ALUMINUM POWDERS
}

\author{
Viktor SKACHKOV, Olga BEREZHNA, Vira ANISHCHENKO, Ruslan GNATYSHAK \\ Zaporizhzhia National University, Zaporizhzhia, Ukraine, skavira@ukr.net, berolgar@ukr.net, \\ 37vera19@gmail.com
}

https://doi.org/10.37904/metal.2021.4236

\begin{abstract}
The conditions for mouldings experimental samples based on aluminum powders of various granulometric composition are presented. The optimal compositions of the charge for pressing, the technology were worked out and the specific pressing pressure was found out, which is $168 \mathrm{MPa}$. Specific density $\left(2.27-2.29 \mathrm{~g} / \mathrm{cm}^{3}\right)$, Brinell hardness $(2.10-2.13 \mathrm{MPa})$ and electrical resistivity $(314-501 \mu \Omega \cdot \mathrm{m})$ were determined experimentally. The effect on the properties of the obtained samples of oxidation processes in the gas phase with different contents of oxygen ions at elevated temperatures up to $520 \mathrm{~K}$ and specific pressure up to $12 \mathrm{MPa}$ was investigated. The concentration of oxygen ions varied from 53 to $70 \mathrm{wt} \%$. The distribution of volume oxidation and its effect on the distribution of properties over the volume of samples were established. The hardness of samples in the near-surface layers increased by $36 \%$, in the centre of the sample by $32 \%$. This distribution of hardness indicates an almost uniform oxidation state of the samples throughout the volume. The increase in the average values of the density of samples by $4 \%$, hardness by $35-40 \%$ and electrical resistance by $15-21 \%$ was determined.
\end{abstract}

Keywords: Aluminum powders, powder pressing, electrical resistivity, oxygen ions, volume increase

\section{INTRODUCTION}

The powder metallurgy finds the widest use for different working conditions of parts and products. By powder metallurgy methods, they produce products with special properties: friction and anti-friction parts of tribology applications, structural nodes and elements, tool and electrotechnical materials; composites of special purpose. The structure of powder aluminum alloys depends on the chemical composition of the alloy and the characteristics of the powder, the technological conditions in pressing, sintering, additive processes and secondary processing operations. Secondary technological operations (forging, rolling and extrusion) are able to increase the density and other functional properties of powder materials, which may exceed the properties of traditional deformable aluminum alloys [1].

The functional properties of parts and nodes based on aluminum are improved by the oxidation method. Oxidation can be carried out by electrolytic methods, by microarc oxidation method [2-4].

Microarc oxidation of aluminum alloys can provide protective anodic spark coatings up to 400 microns thick. The formation of such coatings is possible in various electrolytes [5-7].

Surface hardening and chemical resistance increase are implemented by methods of electrolytic oxidation in an electrolyte made up of organic acids. The ematal process was used to seal the oxide coating.

Volume sintering with simultaneous hardening of powdered blanks provides additive technologies which are implemented on two options.

One option corresponds to the term selective laser sintering. This option implements layered laser sintering of mouldings walls in a thin aligned layer of powder. In the second option, unlike the first, powder material is fed 
directly to a specific place in which the energy is supplied, the process of forming a melt zone and moulding sintering are taking place [9-11].

Improving the structure and functional characteristics over the volume of mouldings based on aluminum powders is a crucial task, both scientific and practical.

\section{THE PURPOSE OF THE WORK}

To assess the possibility of volume oxidation in the oxygen ions media of mouldings based on aluminum powders in conditions of increased pressures and temperatures, to establish experimentally the degree of change in local and integral functional characteristics of mouldings.

\section{MATERIALS AND RESEARCH METHODS}

PA-0 aluminum powders and PAP aluminum powder were used as raw materials. The chemical composition of the components is presented in Table 1.

Pressing of mouldings based on aluminum powders is implemented in cylindrical press die in the conditions of bilateral pressing at $25^{\circ} \mathrm{C}$ and specific pressure of $168 \mathrm{MPa}$ according to the classical technology of powder metallurgy. The composition of the charge for pressing is presented in Table 1. The duration of mouldings holding at maximum pressure was 5 minutes, the pressure of mouldings pressing out was $33 \mathrm{MPa}$.

Table 1 Chemical and granulometric composition of aluminum powders

\begin{tabular}{|c|c|c|c|c|c|c|c|}
\hline Name & $\begin{array}{c}\mathrm{Al} \\
(\mathrm{wt} \%)\end{array}$ & $\begin{array}{c}\mathrm{Fe} \\
(\mathrm{wt} \%)\end{array}$ & $\begin{array}{c}\mathrm{Si} \\
(\mathrm{wt} \%)\end{array}$ & $\begin{array}{c}\mathrm{Cu} \\
(\mathrm{wt} \%)\end{array}$ & $\begin{array}{c}\text { Moisture } \\
(\%)\end{array}$ & $\begin{array}{c}\text { Grain size } \\
\text { composition }(\mu \mathrm{m})\end{array}$ & $\begin{array}{c}\text { Content in the } \\
\text { mouldings material } \\
(\%)\end{array}$ \\
\hline PA-0 & 98.88 & 0.50 & 0.40 & 0.02 & 0.20 & $200-250$ & 93 \\
\hline PAP & 98.99 & 0.35 & 0.40 & 0.05 & 0.25 & $1-30$ & 7 \\
\hline
\end{tabular}

The density of mouldings was determined by hydrostatic weighing and calculated by formula (1):

$\rho=m_{1} \times \rho_{1}\left(m_{1}-m_{2}\right)$

where: $m_{1}$ and $m_{2}$ - the mass of the samples defined in the air and submerged in liquid, respectively; $\rho_{1}$ - fluid density $\left(\mathrm{g} / \mathrm{cm}^{3}\right)$.

The hardness was measured with Brinell test using the $4.0 \mathrm{~mm}$ diameter ball and the $1.05 \mathrm{kH}$ effort application for 30 seconds.

Electrical resistivity was determined on the device P 480 .

The compression strength was determined on cylindrical samples with a diameter of $20 \mathrm{~mm}$ and a height of $20 \mathrm{~mm}$. The tests were carried out on a FP - 100 test machine.

The oxidation of the mouldings was carried out in the autoclave at a pressure of $6.5 \mathrm{MPa}$ and a temperature of $510 \mathrm{~K}$ in the oxygen ions media. The oxidation time was 30 minutes. The cooling was carried out with the autoclave.

\section{RESULTS}

For the preparation of the charge, subsamples of 930 grams of aluminum powder (PA- 0 ) and 70 grams of aluminum powder (PAP) were taken. The subsamples were mixed in a vibrating mixer for 30 minutes until the components were distributed homogeneously by volume. The mouldings were pressed in accordance with section 3. 
The characteristics of the mouldings samples were determined by the methods outlined in section 3 and presented in Table 2.

Table 2 Parameters of mouldings characteristics prior to the oxidation process

\begin{tabular}{|c|c|c|c|c|}
\hline Sample No. & $\begin{array}{c}\text { Density } \\
\left(\mathrm{g} / \mathrm{cm}^{3}\right)\end{array}$ & $\begin{array}{c}\text { Hardness HB } \\
(\mathrm{MPa})\end{array}$ & $\begin{array}{c}\text { Compression strength } \\
(\mathrm{MPa})\end{array}$ & $\begin{array}{c}\text { Electrical resistivity } \\
(\mu \Omega \cdot \mathrm{m})\end{array}$ \\
\hline 1 & 2.293 & 2.223 & 37 & 314 \\
\hline 2 & 2.271 & 2.192 & 39 & 326 \\
\hline 3 & 2.275 & 2.137 & 41 & 367 \\
\hline 4 & 2.267 & 2.133 & 43 & 385 \\
\hline 5 & 2.264 & 2.108 & 44 & 501 \\
\hline 6 & 2.270 & 2.189 & 42 & 478 \\
\hline
\end{tabular}

Table 2 tested data show that the average density of samples is $2.52 \mathrm{~g} / \mathrm{cm}^{3}$, the average hardness is 2.164 $\mathrm{MPa}$, the average electrical resistivity is $395 \mu \Omega \cdot \mathrm{m}$ and the average compression strength is $41 \mathrm{MPa}$.

The obtained samples were processed by autoclave oxidation in media containing different concentration of oxygen ions. The diffusion activity of oxygen ions in high pressure conditions up to $6.5 \mathrm{MPa}$ ensured the process of mouldings oxidation over their volume. Characteristics of oxidized mouldings samples are presented in Table 3.

Table 3 Characteristics of oxidized mouldings samples

\begin{tabular}{|c|c|c|c|c|c|c|c|c|c|c|}
\hline $\begin{array}{c}\text { Sample } \\
\text { No. }\end{array}$ & $\begin{array}{c}\text { Oxygen } \\
\text { ions } \\
(\%)\end{array}$ & $\begin{array}{c}\text { Weight } \\
(\mathrm{g})\end{array}$ & $\begin{array}{c}\text { Weight } \\
\text { increase } \\
(\%)\end{array}$ & $\begin{array}{c}\text { Diamete } \\
\mathbf{r}(\mathrm{mm})\end{array}$ & $\begin{array}{c}\Delta \boldsymbol{D} \\
(\%)\end{array}$ & $\begin{array}{c}\text { Height } \\
(\mathrm{mm})\end{array}$ & $\begin{array}{c}\Delta \boldsymbol{I} \\
(\%)\end{array}$ & $\begin{array}{c}\text { HB } \\
(\mathrm{MPa})\end{array}$ & $\begin{array}{c}\text { Strength } \\
(\mathrm{MPa})\end{array}$ & $\begin{array}{c}\text { Electrical } \\
\text { resistivity }(\mu \Omega \cdot \mathrm{m})\end{array}$ \\
\hline 1 & 53.2 & 14.97 & 4.2 & 20.2 & 1.0 & 20.8 & 1.5 & 3.01 & 78 & 361 \\
\hline 2 & 53.2 & 15.73 & 4.5 & 20.3 & 1.5 & 22.0 & 1.8 & 3.01 & 79 & 366 \\
\hline 3 & 56.9 & 16.21 & 4.7 & 20.3 & 1.5 & 22.4 & 2.1 & 2.87 & 74 & 445 \\
\hline 4 & 56.9 & 16.21 & 4.8 & 20.4 & 2.0 & 23.0 & 2.2 & 2.93 & 76 & 446 \\
\hline 5 & 70.1 & 16.14 & 4.5 & 20.3 & 1.5 & 22.7 & 1.3 & 2.84 & 73 & 562 \\
\hline 6 & 70.1 & 15.60 & 3.8 & 20.1 & 0.5 & 21.9 & 0.8 & 3.03 & 79 & 550 \\
\hline
\end{tabular}

The results of the studies presented in Table 2 and Table 3 showed that the hardness of the processed mouldings samples increased by an average of $40.7 \%$, the electrical resistivity increased by $14.9 \%$, and the compression strength increased by almost 2.09 times.

The average increase in weight was between 3.8 and $4.8 \%$, the diameter $(\Delta D)$ was increased by 0.5 to $2.0 \%$, the length $(\Delta l)$ was increased by $0.8-2.2 \%$.

It is important to distribute the characteristics of the samples over their volume. The distribution by volume of Brinell hardness samples is presented as an example. To this end, the samples were cut in height into two equal parts after pressing and oxidation process. On upper, middle and lower surfaces of the sample at 0.25 radius $(R)$ intervals, starting from the centre of the surfaces, the Brinell hardness HB was determined. The hardness distribution results are presented in Table 4. From the analysis of the obtained results, it follows that the samples after pressing have the hardness in the centre lower by $1.8-1.9 \%$ than near the outer surface. Samples after the oxidation process on the upper radius have a difference of up to $1.4 \%$, on the lower radius $-0.99 \%$, on the central radius $-0.72 \%$. Height along in the centre of samples the difference between the top and the middle for samples after pressing is $1.4 \%$, for oxidized samples is $0.16 \%$. 
Table 4 Distribution of the hardness HB (MPa) of moulding samples by height and radius $(R)$ before and after the oxidation process

\begin{tabular}{|c|c|c|c|c|c|c|c|c|c|c|}
\hline \multirow[t]{2}{*}{ Height } & \multicolumn{2}{|c|}{$0.00 R$} & \multicolumn{2}{|c|}{$0.25 R$} & \multicolumn{2}{|c|}{$0.50 R$} & \multicolumn{2}{|c|}{$0.75 R$} & \multicolumn{2}{|c|}{$1.00 R$} \\
\hline & Pressing & Oxidation & Pressing & Oxidation & Pressing & Oxidation & Pressing & Oxidation & Pressing & Oxidation \\
\hline Top & 2.18 & 3.018 & 2.19 & 3.039 & 2.201 & 3.040 & 2.20 & 3.049 & 2.22 & 3.052 \\
\hline Middle & 2.15 & 3.020 & 2.16 & 3.022 & 2.181 & 3.027 & 2.18 & 3.033 & 2.19 & 3.042 \\
\hline Bottom & 2.19 & 3.025 & 2.19 & 3.043 & 2.203 & 3.051 & 2.21 & 3.053 & 2.22 & 3.055 \\
\hline
\end{tabular}

The difference in hardness in the outer radius between the top and the middle for samples after pressing was $1.3 \%$, and for oxidized samples $0.33 \%$. The calculations presented show that the diffusion processes of oxygen ions in autoclave oxidation conditions are well developed and provide a high homogeneity of properties over the volume of samples.

\section{CONCLUSIONS}

Volume oxidation of mouldings based on aluminum powders in conditions of increased pressure up to $6.5 \mathrm{MPa}$ and temperature up to $510 \mathrm{~K}$ in the oxygen ions media allowed to increase the Brinell hardness by $40.7 \%$, to raise the electrical resistivity by almost $15 \%$ and increase the compression strength by 2.09 times. It was established experimentally that the hardness of the samples after the volume oxidation process is almost evenly-distributed over the volume, the maximum difference in Brinell hardness values does not exceed $0.33 \%$.

\section{REFERENCES}

[1] TOTTEN G. E., TIRYAKIOĞLU M. Powder metallurgy aluminum alloys: Structure and porosity. Encyclopedia of aluminum and its alloys. CRC Press, Taylor and Francis, Boca Raton, FL- 2019

[2] NIKOLAEV, A.V., MARKOV, G.A., PESHCHEVITSKY, B.I. New phenomenon in electrolysis. Izvestiya SB AS USSR. Chemical Science Series. 1977, vol. 5, no. 12, pp. $32-33$.

[3] MARKOV G.A., MARKOVA G.V. Method of forming anodes of electrical capacitors - A.S. 526961 USSR, MKI N 01 G 9/24.No. 1751524 / 26-21; declared 02.24.72; publ. 08/30/76, Bul. No. 32

[4] SHKILKO, A.M., TIKHONENKO A.M. Analysis of the method of hardening parts with microarc oxidation. Bulletin of the National Technical University "KhPl": zb. Sciences. good. Thematic bulletin: New solutions in modern technologies. 2010, no. 46, pp. 252-257.

[5] EPELFELD, A.V. Application of microarc oxidation technology for the formation of protective coatings. Mechanical Engineering Technology. 2004, no. 4, pp. 39-44.

[6] PAVLYUS, S.G., SOBORNITSKIY, V.I., SHEPRUT, Yu.A. Dielectric properties of anodic spark silicate coatings on aluminum. Electronic Processing of Materials. 1987, no. 3, pp. 34-36.

[7] BAKOVETS, V.V., DOLGOVESOVA, I.P., NIKIFIROVA, G.L. Oxide films obtained by processing aluminum alloys in concentrated sulfuric acid in anodic-spark mode. Protection of Metals. 1986, vol. 22, no. 3, pp. 440444.

[8] GRILIKHES, S.Ya. Oxide and phosphate coatings of metals. Mechanical Engineering. 1985, $280 \mathrm{p}$.

[9] HORN T., HARRYSSON O. Overview of current additive manufacturing technologies and selected applications. Science Progress. 2012, vol. 95, no. 3, pp. 255-282.

[10] GREUL, M. Metal and ceramic prototypes using the multiphase jet solidification (MJS) process Metallische und keramische Prototypenmitdem Multiphase jet Solidification (MJS) Verfahren. Fraunhofer IFAM In: Conference on Rapid Tooling \& Manufacturing 1997. Proceedings Aarhus.

[11] SABINA, L., CAMPANELLI, CONTUZZI, N. Capabilities and performances of the Selective Laser Melting process. Polytechnic of Bari, Department of Management and Mechanical Engineering, Viale Japigia, 182 Italy [online] 2010. [viewed: 2021-05-17]. Available from: https://cdn.intechopen.com/pdfs/12285/InTechCapabilities and performances of the selective laser melting process.pdf 